\begin{tabular}{|l|}
\hline 講 \\
\hline
\end{tabular}

强靶鋼

會員錦緎清治

\title{
2. マンガン鎆
}

\section{a） マンカン銿の組㵝}

第 8 圖は鐵-マンガン系平衡狀態圆て，鐵側 に於ける包晶反應の部及び $A_{8}$ 變態點がマン ガン含量により降下する樣子等は鐵-ニッケル 系の場合と類似して居る。

第 8 圆

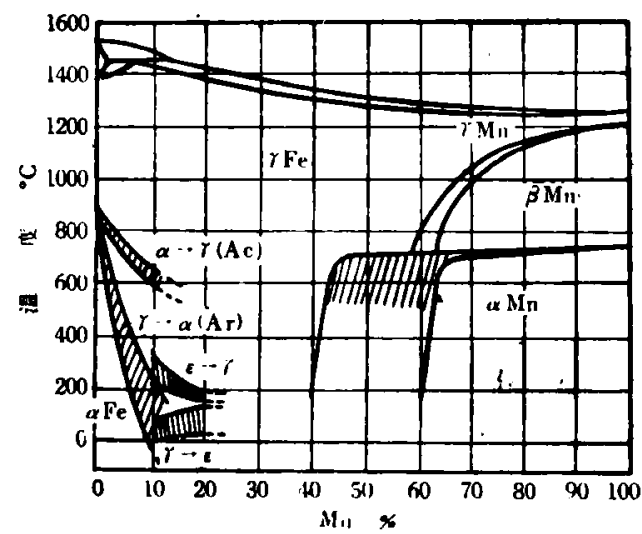

マンガンは合金元素としても有用であるお

特に精鍊上缺くくからざる元素である．從つ て本系狀態圖は鐵合金狀態圖中最も緊要なる ものであるか，其の決定を見たのは最近のこ とである．其の理由は純マンガンせ得る事少; 著しく困難で本二元系の研究用試料を作り得 お，及マンガンに變態點がる篇其の二元
系狀態圆の構成が著しく難しかつたためで ある。

マンガン側は賽用合金としては餘り關係が ないから說明を省き，鐵側について說明する そ, $\mathrm{A}_{3}$ 變態點は鐵-ニッケル 合金の場合の如 く降下する．其の降下の割合はニッケルの湯 合に比較するとニックル含量の牛分量のマン ガンで同等な作用があう。、ンガン含量 $10 \%$ 以上になると $\varepsilon$ と云ふ六角柱狀結晶の相か； 現れ，此の種の相は鐵-ニックル合金には現れ ない. 又加熱と冷却とで $\mathrm{A}_{3}$ 變態點扒不可 逆になるのは鐵ニニッケル合金の場合と同樣で ある。

鐵-マンガン・桨素の三元系合金は工業上非 常に有用で且今日廣く用ひられて居るが，本 釆狀態圆は未だ決定されて居ない。

㷋素が合金すると鐵-マンガン合金の不可 逆性は更に著しくなり，其つ平衡狀態を得る 事は始ど不可能であるから本三儿系狀態圖の 研究は容易ではない。

本三元系に有用範圍少三つある，其り一位 鐵側に於ける部で所謂デューコール鋼の組成 範圍でマンガンを約 $2 \%$ 含有する構造用鋼で 
ある.其の二は高マンガン鋼の組織範園で，

マンガン約 $12 \%$ ，炭素約 $1 \%$ 含有するオー

ステナィト鋼である。其の三はマンガン約

70\%，䈐素約 7\%のフェローマンガンである。

フェロ・マンガンにはマンガン含量の更に低值

のきの，炭素含量の低いもの等あるが，70\%

第 9 圆 $900^{\circ} \mathrm{C}$ より継徐命却

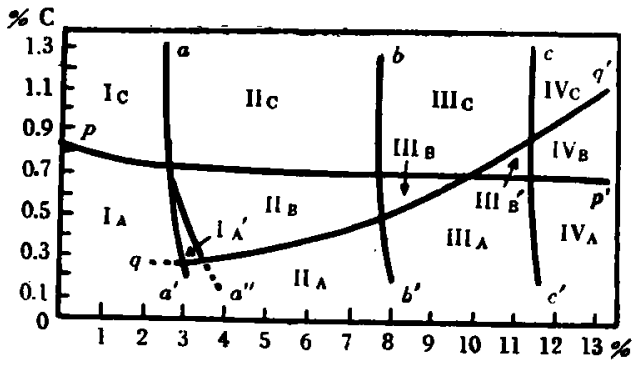

のものが代表的である.

次に村上博士によるマンガン $13 \%$ 以下，炭 素 $1.3 \%$ 以下わ本三元系合金の諸冷却條件下

に於ける化學組成と組織との關係を示すと第 9,10,11 圆の樣である.
第 10 圆 $900^{\circ} \mathrm{C}$ より媪中掵却

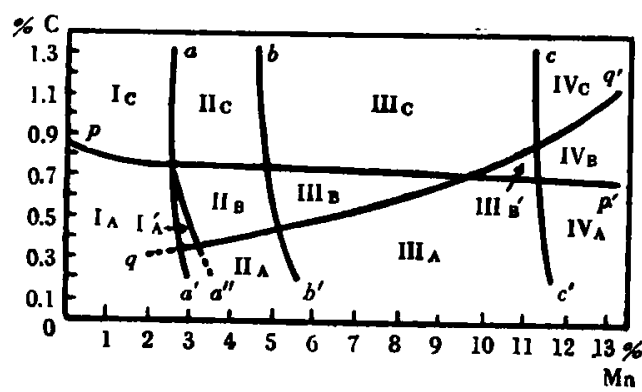

第 11 圆 $900^{\circ} \mathrm{C}$ 上り空中命却

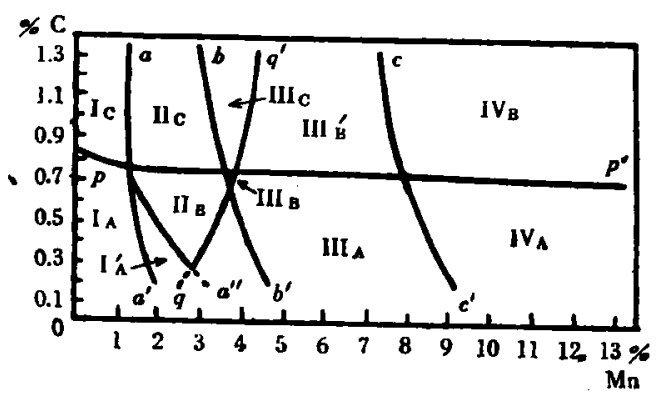

圖中の附號と組織との關係は次の樣である。

附號中

Fはフェライト

$P$ はパーライト

M はマルテンサイト

Tはトールスタイト

A はオーステナイト

C 初析炭化物

Is $\mathbf{F}+\mathrm{P}$

$I_{\mathbf{A}^{\prime}} \quad \mathrm{F}+\mathrm{T}+\mathrm{M}$

Ic $\mathrm{P}+\mathrm{C}$
II $\mathbf{M}$

II $_{B} \quad T+M$

IIc $\mathrm{T}+\mathrm{M}+\mathrm{C}$

III $_{\mathbf{A}} \mathbf{M}+\mathbf{A}$

III $_{B} \quad \mathrm{M}+\mathrm{T}+\mathrm{A}$

III $^{\prime} \quad \mathrm{M}+\mathrm{A}+\mathrm{C}$

IIIc $\mathbf{M}+\mathrm{T}+\mathrm{A}+\mathrm{C}$

$\mathrm{IV}_{\mathbf{A}} \mathrm{A}$

IV $\mathrm{A}+\mathrm{C}$

IVc $\mathrm{A}+\mathrm{C}+\mathrm{T}$

宗す。 
第 12,13 圆は $900^{\circ} \mathrm{C}$ 及び $1200^{\circ} \mathrm{C}$ から燒 入れた場合の組織圖で，燒入液は油又は水て

第 12 圆

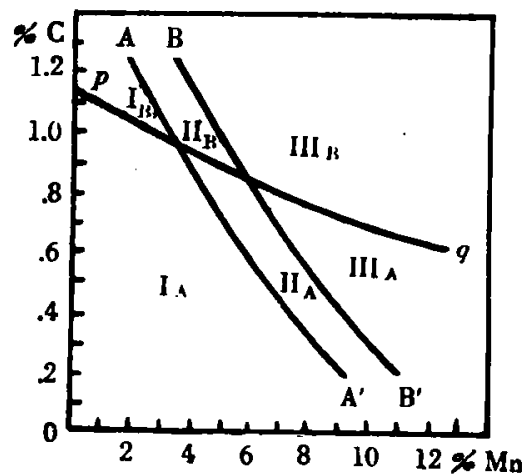

第 13 圖

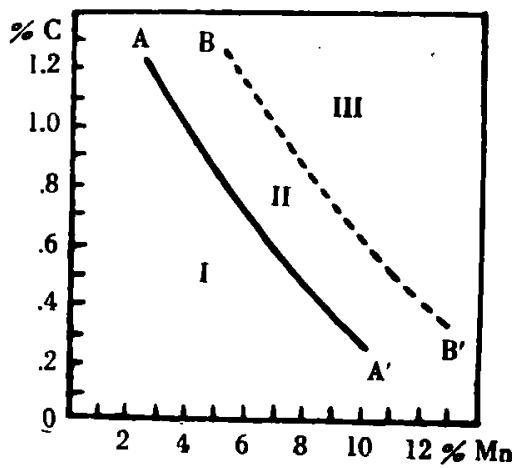

ある。圖中界域 Iは主としてマルテンサイ トによりなるもの，界域 II はマルテンサイ トとオーステナイトとょりなるるの，界域 III 。 はオーステナイトよりなるものである.第 12 圖 $p q$ 線より上方は炭化物の認められる部 で, $1200^{\circ} \mathrm{C}$ 燒入では炭化物は現れない。

低マンガン構造用鍴に添加されたマンガン の役割は主として變態點の降下を容易ならし める事で，炭素鋼に比較して其の燒入燒㞔狀 態に於ける性質が優秀である。

師古炭素鋼で $500^{\circ} \sim 630^{\circ} \mathrm{C}$ の燒戻て 50〜 $80 \mathrm{~kg} / \mathrm{mm}^{2}$ の抗張力で使用されるが，マンガ ンの合金された鋼では 70 95 $\mathrm{kg} / \mathrm{mm}^{2}$ の降
伏點て使用する事が出來る。

マンガン鋼の缺點は加熱に際して結晶粒の 成長し易い事で，此の缺點节防ぐためにク口 ム・タングスラン・ヴァナヂウム等を合金す る . 是等の合金元素の微量の添加によつて性 質が著しく改善されるから高級鋼では單獨な マンガン鋼は少い，結晶粒の成長に關するー ンガン鋼の敏感性を是等の元素の添加によつ て改善し得る理由として, 炭化物のオーステ ナイトに對する溶解速度小遲くなるためであ ると說明する人があるか，其の真嗣は問で ある.

又鋼材の方向性による衛擊値の變化の著し い事も本鋼種の缺點で，例へばニックル・ク口

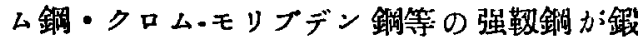
伸方向に直角な方向の衝䣫か：平行な方向の それの約 50\%であるが、 、ンガン鋼では $25 \%$ 程度に過きない。

其の理由の一つとしては マンガンシリ ケート・マンガンサルファイド等は何れも非 常に鼠伸性に富むから是等の非金均性介在物 が鉣伸方向に伸びて所謂繊維組織となるから である.從つて例へば鈑發條の樣な荷重の方 向が常に定まつたものでは却つて此の繊維組 織のものか强い場合がある。

マンガン鋼か矩條として廣く用ひられる一 つの所以である.

又マンガンを工具鋼に加へると憢入に際し て變形度の少い性質を與へる。共析鋼に約 2\% マンガンき加へたものが不收縮鋼の基礎 になる鋼であるが，本編では强䩲鋼につい てのみ遬べる踭定であるから詳しくは倹か ない. 


\section{b. 惯用鋼種と其の用途}

今本䤵種の化學組成と用途とを示すと第 9 表の㥞である，郎ち强勒鋼として使用される のは $1,2,3,4$ 及び $6 て ゙ ， 5$ は具鋼である.
此の队 $1,2 ３ ， 4$ は低マンガン構造用鋼て パーライト鋮で，6は高マンガン，オーステナ イト鋼である。

第 9 表

\begin{tabular}{|c|c|c|c|}
\hline & C & Mn & 途 \\
\hline 1 & $0.4-0.6$ & $0.7-1.2$ & 金型, 金敂 \\
\hline 2 & $0.1-0.4$ & $0.5-2.5$ & 鎔接用心線 \\
\hline 3 & $0.3-0.45$ & $1.0-1.8$ & 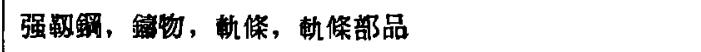 \\
\hline 4 & $0.4-0.5$ & $1.6-2.0$ & 板バネ，土木・㬡山用諸機械部品 \\
\hline 5 & $0.8-1.2$ & $1.4-2.0$ & ステーポールト用タップ反びリルカカリバーダーキ \\
\hline 6 & $0.9-1.4$ & $10 \cdot 0-15 \cdot 0$ & 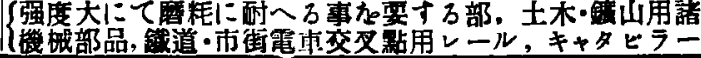 \\
\hline
\end{tabular}

第 10 表は炭素含量の低いマンガン鋼の憢 したものである。

入溫度・燒戻溫度と機的的性質との關係示示＼cjkstart第 11 表は含炭量 $0.4 \%$ 及び $0.6 \%$ 系の

第 10 表

\begin{tabular}{|c|c|c|c|c|c|c|c|c|}
\hline 成 & 分 & $\%$ & 燒入温度 & 燒展溫度 & 降伏點 & 抗張力 & 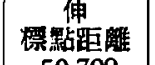 & 較 \\
\hline C & $\mathrm{Si}$ & $\mathbf{M n}$ & ${ }^{\circ} \mathrm{C}$ & ${ }^{\circ} \mathrm{C}$ & $\mathrm{kg} / \mathrm{mm}^{2}$ & $\mathrm{~kg} / \mathrm{mm}^{2}$ & 2 回の平均 & $\%$ \\
\hline 0.12 & 0.29 & 2.16 & 880 & 565 & 52.1 & 64.0 & 29.5 & 70.8 \\
\hline 0.155 & 0.07 & 1.64 & 880 & 565 & 45.8 & 59.6 & 25.5 & 72.5 \\
\hline 0.12 & 0.51 & 1.46 & 930 & 565 & 50.5 & 66.8 & 28.0 & 69.0 \\
\hline 0.205 & 0.44 & 1.64 & 930 & 565 & 39.0 & 52.1 & 29.0 & 75.7 \\
\hline 0.275 & 0.10 & 1.97 & 880 & 430 & 100.5 & 118.5 & 11.5 & 36.6 \\
\hline 0.22 & 0.38 & $2.50^{\circ}$ & 880 & 430 & 103.1 & 119.8 & 11.5 & 43.6 \\
\hline 0.22 & 0.38 & 2.50 & 990 & 430 & 102.2 & 125.6 & 12.5 & 41.1 \\
\hline 0.20 & 0.13 & 2.38 & 1050 & 430 & 96.8 & 119.4 & 14.0 & 52.6 \\
\hline 0.29 & 0.45 & 2.43 & 880 & 320 & 91.0 & 141.8 & 8.5 & 26.1 \\
\hline 0.275 & 0.10 & 1.97 & 930 & 320 & 94.0 & 142.2 & 6.5 & 21.I \\
\hline 0.22 & 0.38 & 2.50 & 990 & 320 & 93.8 & 140.7 & 10.0 & 35.6 \\
\hline 0.29 & 0.45 & 2.43 & 1050 & 320 & 87.5 & 146.7 & 12.5 & 43.6 \\
\hline
\end{tabular}

第 11 表

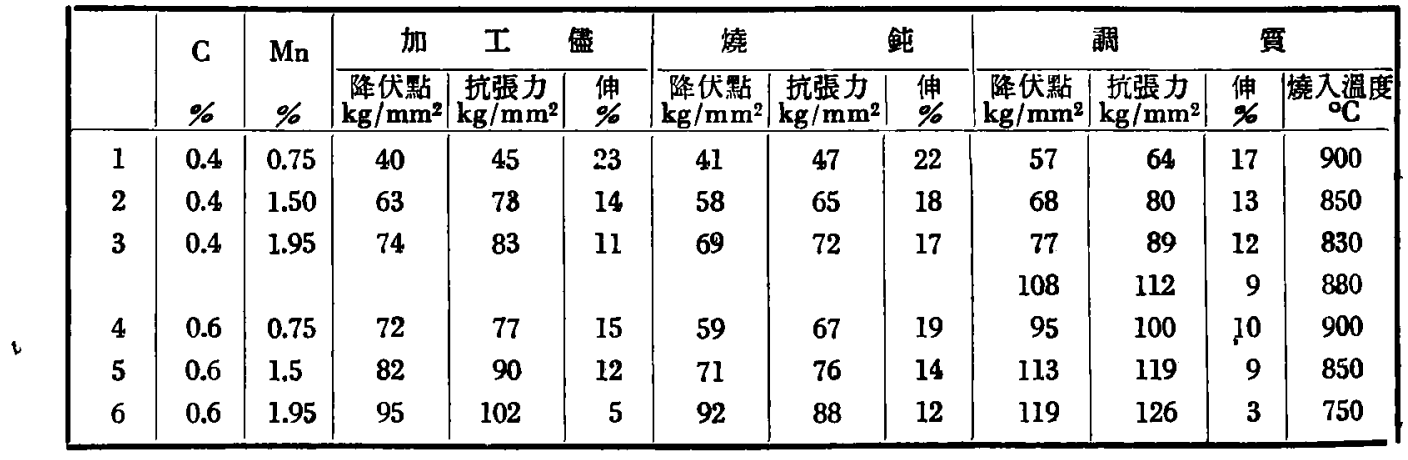


のの諸性質で，安價なダイブロック用素材 として用ひられる．其の他高力を必要とする 部て餘り重要でない部に用ひられる。

第 12 表は C 0.37\%, Mn 1.78\%の鋼な $800^{\circ}$ Cから燒入れた。のを $550^{\circ} \mathrm{C}$ 以上の諸溫度 で憢送した場合の機械的諸性質である。

第 12 表 $\quad 0.37 \% \mathrm{C}, 1.78 \% \mathrm{Mn}$

\begin{tabular}{|c|c|c|c|c|c|}
\hline $\begin{array}{l}\text { 橈入 } \\
\text { 溫度 } \\
{ }^{\circ} \mathrm{C}\end{array}$ & $\begin{array}{l}\text { 墭底 } \\
\text { 度 } \\
\text { 。 }\end{array}$ & $\begin{array}{c}\text { 降伏點 } \\
\mathrm{kg} / \mathrm{mm}^{2}\end{array}$ & $\begin{array}{c}\text { 抗張力 } \\
\mathrm{kg} / \mathrm{mm}^{2}\end{array}$ & $\begin{array}{l}\text { 伸 } \\
\%\end{array}$ & $\begin{array}{l}\text { 棭 } \\
\%\end{array}$ \\
\hline 800 & 550 & 79 & 100 & 10.6 & 15 \\
\hline 800 & 600 & 75 & 98 & 12.5 & 23 \\
\hline 800 & 650 & 66 & 88 & 13.1 & 27 \\
\hline 800 & 680 & 61 & 82 & 17.8 & 30 \\
\hline
\end{tabular}

マンガン銅は $500^{\circ} \mathrm{C}$ 以下の憢戻では著し く脆弱である，又燒戻脆性に對しても著しく
敏感である。

是等の低マンガンバーライト鋼は所謂 デューコール鋼と稱せらる〉当ので,造船・土 建等で用いらるっ合金鋼としては其の消費量 は最も多量である。

S. A. E. No. 1112, 1115, 1120, 1314, 1315, $1330,1335,1340$ はフリーカッテング鋼と 稱して切削能率の良好な䞒である。切削能率 を特に良好ならしめるため燐・硫黄等の含量 を普通より高くしておるが，此の爲に生する 赤熱脆性防くためマンガンが最高 $1.65 \%$ 合金してあるから此の種の銅も亦マンガン鋼 と稱すべきである。第 13 表に是等鋼種の分 析規格を示した。

第 13 表

\begin{tabular}{|c|c|c|c|c|}
\hline $\begin{array}{c}\text { S. A. E. } \\
\text { No. }\end{array}$ & 屍 $\begin{array}{c}\text { 素 } \\
\%\end{array}$ & $\begin{array}{c}\text { マンガン } \\
\%\end{array}$ & $\begin{array}{c}\text { 燐 } \\
\%\end{array}$ & 硫 \\
\hline 1112 & $0.08-0.16$ & $0.60-0.90$ & $0.09-0.13$ & $0.10-0.20$ \\
$\times 1112$ & $0.08-0.16$ & $0.60-0.90$ & $0.09-0.13$ & $0.20-0-30$ \\
1115 & $0.10-0.20$ & $0.70-1.00$ & $0.045 \max$ & $0.075-0.15$ \\
1120 & $0.15-0.25$ & $0.60-0.90$ & $0.045 \max$ & $0.075-0.15$ \\
$\times 1314$ & $0.10-0.20$ & $1.00-1.30$ & $0.045 \max$ & $0.075-0.15$ \\
$\times 1315$ & $0.10-0.20$ & $1.30-1.60$ & $0.045 \max$ & $0.075-0.15$ \\
$\times 1330$ & $0.25-0.35$ & $1.35-1.65$ & $0.045 \max$ & $0.075-0.15$ \\
$\times 1335$ & $0.30-0.40$ & $1.35-1.65$ & $0.045 \max$ & $0.075-0.15$ \\
$\times 1340$ & $0.35-0.45$ & $1.35-1.65$ & $0.045 \max$ & $0.075-0.15$ \\
\hline
\end{tabular}

次に高マンガンオーステナイト鋼につい て述べる。

高マンガン鋼は ロパートハッドフォルド 氏か：1882年發見せる。のて，高溫度より燒

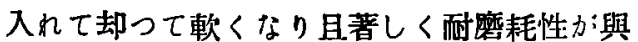
へられる事が英國の特許になつてるる．此の 事實は現在の吾々の冶金學的知識からは當然 と考へられるか，當時は全く奇異な現象であ つた.
本鋼種は鋸造物としても銡物としても使用 されるか，其の機械加工か：著しく困踓なため

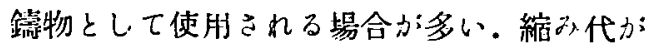
大きい雹鑄物の製作は困難であるか晹流れは 非常に良いから相當複雜な製品吕㓟作する事 か出來る。

高マンガン銅は硬度は比較的低いぷバイ ト・ドリルによう加工少著しく困難である。そ れは常溫加工によつてマルテンサイトが出來 
るためで，扣硬化ぷバーライト銅より著し いためであ己。降伏點ふ低いにかつはらす抗 張力し高いりき同栐な理由で普避のブリネル 硬度對抗張力り關係式ふら求めた抗張力ょり 貝際の抗張力心著しく高い，第 14 表は是等

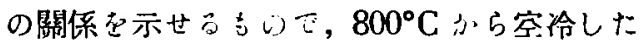

ものか此の關係方逆になつて居るのは析出舞 化物の量の多いためで破斷迄の加工硬化が少 いためである。

鍺造儘の組織か＼cjkstart第 14 圖の榚で，結晶粒界 に岑化物が多量にある，此の岩化物が全部 オーステナイト結晶に固溶してしまつたすの

第 14 表

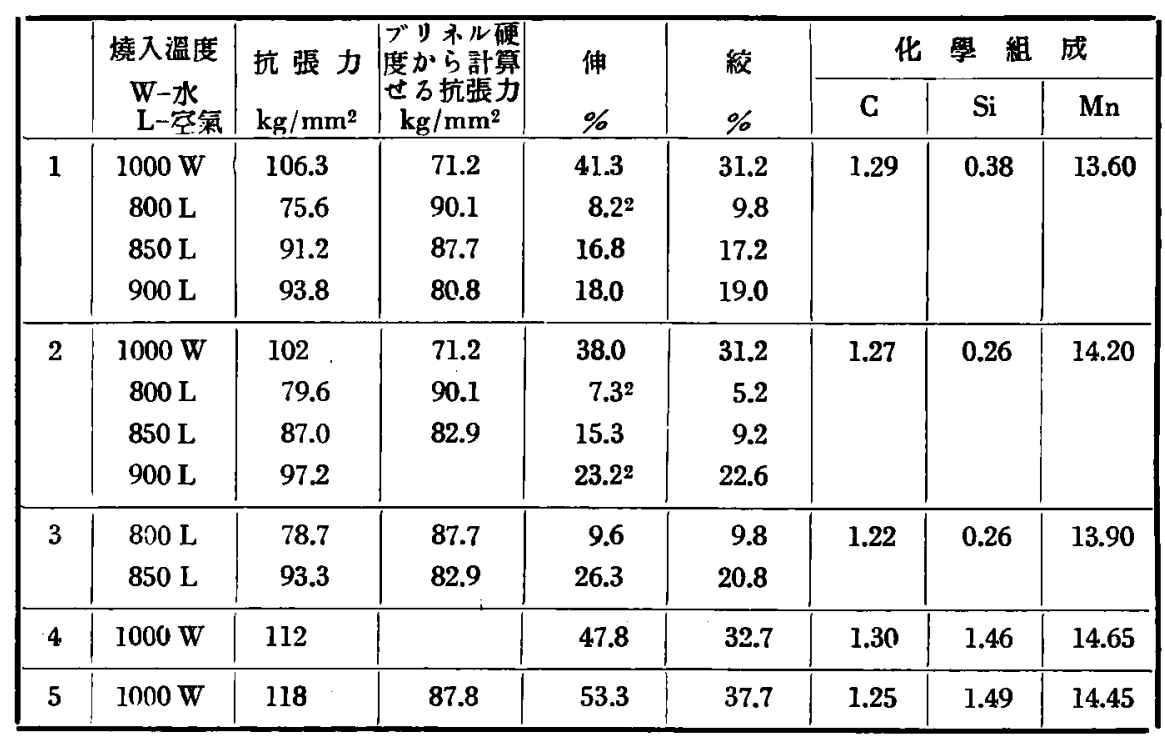

第 14 圖

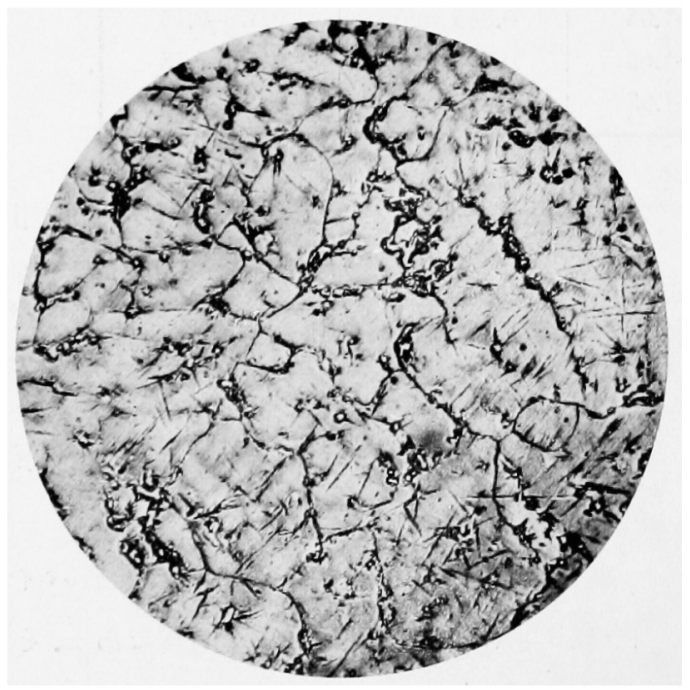

\begin{tabular}{|c|c|c|c|}
\hline & 䓣 & 俺 & \\
\hline 喠種 & \multicolumn{3}{|c|}{ MMM } \\
\hline \multirow{2}{*}{ 成分 } & $\begin{array}{l}C=1.21 \\
P=0.040\end{array}$ & $\begin{aligned} \mathrm{Si} & =0.30 \\
\mathrm{~S} & =0.008\end{aligned}$ & $\begin{aligned} \mathrm{Mn} & =13.68 \\
\mathrm{Ni} & =\end{aligned}$ \\
\hline & $\begin{aligned} \mathrm{Cr} & = \\
\mathrm{V} & =\end{aligned}$ & $\begin{aligned} \mathrm{Cu} & =0.20 \\
\mathrm{Mo} & =\end{aligned}$ & $\begin{array}{l}W= \\
C_{0}=\end{array}$ \\
\hline 恖理 & \multicolumn{2}{|l|}{ 銀故の儘 } & \\
\hline 硬度 & B.H.N. 241 & 倍率 & $\times 50$ \\
\hline 揗蝕 & \multicolumn{3}{|c|}{$5 \%$ ピクリン酸アルコール } \\
\hline 組織 & \multicolumn{3}{|c|}{ オーステナイト+カーバイト } \\
\hline
\end{tabular}


が高マンガン銓としての特性棸發揮する。

郎古伸が $50 \%$ 以上とをなり，加工による 硬化度方高く耐磨耗性少强い。

岸化物吉完全に消失せしめるには $900^{\circ} \mathrm{C}$ 以上の加熱少必要で,普通 $1050^{\circ} \mathrm{C}$ 水冷が行 はれて居る。

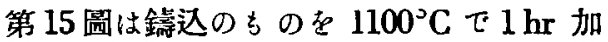
熱媵水冷せるもので結晶粒界の炭化物が完全
に消失して居る，樹狀晶が見えうのはマンガ ン・燐等の偏析か此の加熱操作で消失せしめ る事少出來なかつた篇て良く法心い小，炭化 物の析出しだきの程の惡影響はない。

第 16 圖は鍛鍊後 $1050^{\circ} \mathrm{C}$ て $1 \mathrm{hr}$ 加熱後水 冷せるもので完全なオーステナイト結晶分示 して居る。
第 15 圆

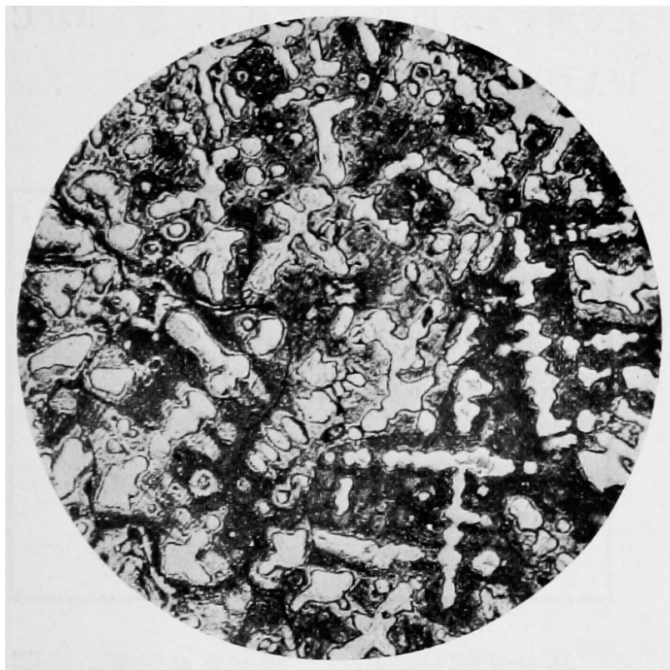

第 16 圆

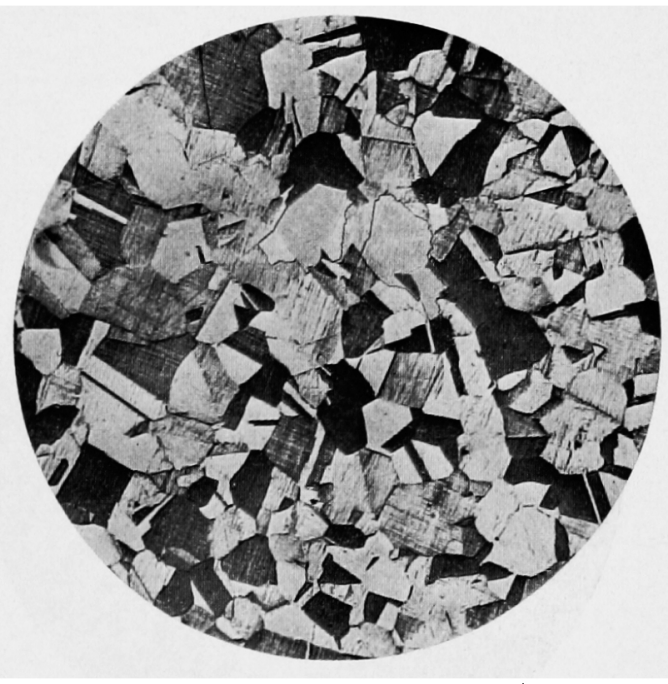

\begin{tabular}{|c|c|c|c|}
\hline & 䨕 & 俺 & \\
\hline 鋼種 & \multicolumn{3}{|c|}{ MMM } \\
\hline \multirow{2}{*}{ 成分 } & $\begin{array}{l}\mathrm{C}=1.21 \\
\mathrm{P}=0.040\end{array}$ & $\begin{aligned} \mathrm{Si} & =0.30 \\
\mathrm{~S} & =0.008\end{aligned}$ & $\begin{aligned} \mathrm{Mn} & =13.68 \\
\mathrm{Ni} & =\end{aligned}$ \\
\hline & $\begin{aligned} \mathrm{Cr} & = \\
\mathrm{V} & =\end{aligned}$ & $\begin{aligned} \mathrm{Cu} & =0.20 \\
\mathrm{Mo} & =\end{aligned}$ & $\begin{array}{l}W= \\
C_{0}=\end{array}$ \\
\hline 處理 & \multicolumn{3}{|c|}{$1100^{\circ} \mathrm{C} \times 1 \mathrm{hr}$ 水銝 } \\
\hline 䂠度 & B.H.N. 18 & $\|$ 倍事 & $\times 100$ \\
\hline 腐蝕 & \multicolumn{3}{|c|}{$5 \%$ ピクリン酸アルコール } \\
\hline 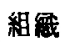 & \multicolumn{3}{|c|}{ オーステナイト } \\
\hline
\end{tabular}

\begin{tabular}{|c|c|c|c|}
\hline & 濔 & 俺 & \\
\hline 铜種 & \multicolumn{3}{|c|}{ MMM } \\
\hline \multirow{2}{*}{ 成分 } & $\begin{array}{l}C=1.21 \\
P=0.049\end{array}$ & $\begin{aligned} \mathrm{Si} & =0.36 \\
\mathrm{~S} & =0.007\end{aligned}$ & $\begin{aligned} \mathrm{Mn} & =13.72 \\
\mathrm{Ni} & =\end{aligned}$ \\
\hline & $\begin{aligned} \mathrm{Cr} & = \\
\mathrm{V} & =\end{aligned}$ & $\begin{aligned} \mathrm{Cu} & =0.20 \\
\mathrm{Mo} & =\end{aligned}$ & $\begin{array}{l}W= \\
\mathrm{Co}_{0}=\end{array}$ \\
\hline 處理 & \multicolumn{3}{|c|}{$1050^{\circ} \mathrm{C} \times 1 \mathrm{hr}$ 水中燒入 } \\
\hline 硬度 & & 倍率 & $\times 100$ \\
\hline 磨蝕 & \multicolumn{3}{|c|}{$1 \%$ 䃃酸アルコール } \\
\hline 組織 & \multicolumn{3}{|c|}{ オーステ+イト } \\
\hline
\end{tabular}




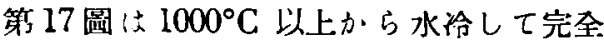
にオーステナイト組織にした高マンガン鋼を

第 17 圖

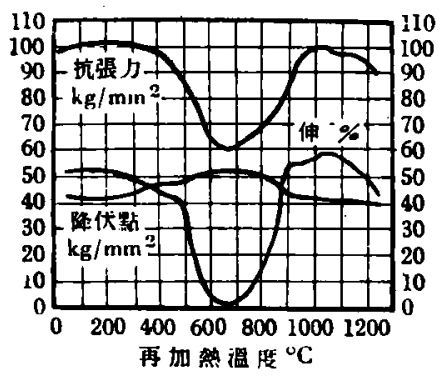

第 18 圖

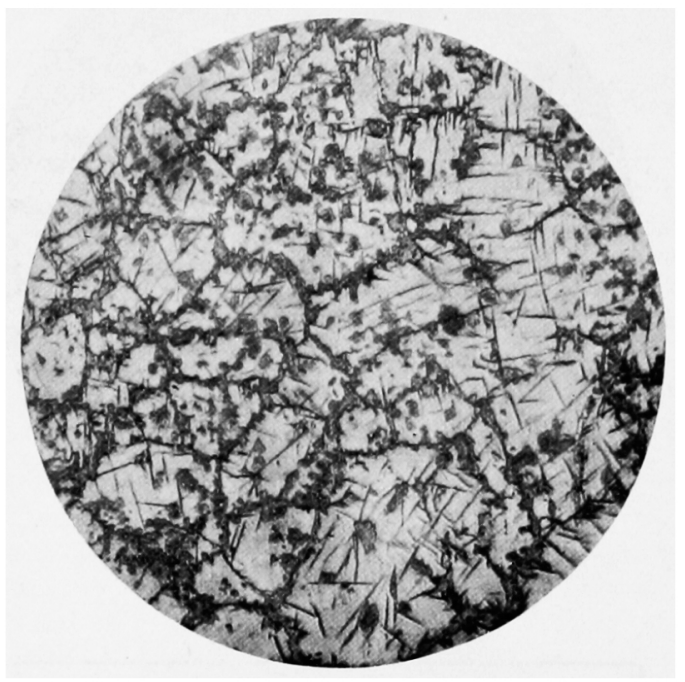

\begin{tabular}{|c|c|c|c|}
\hline & 滿 & 俺 & \\
\hline 輭種 & \multicolumn{3}{|c|}{ MMM } \\
\hline \multirow{2}{*}{ 成分 } & $\begin{array}{l}C=1.24 \\
P=0.035\end{array}$ & $\begin{aligned} \mathrm{Si} & =0.54 \\
\mathrm{~S} & =0.010\end{aligned}$ & $\begin{aligned} \mathrm{Mn} & =13.53 \\
\mathrm{Ni} & =\end{aligned}$ \\
\hline & $\begin{aligned} \mathrm{Cr} & = \\
\mathrm{V} & =\end{aligned}$ & $\begin{array}{l}\mathrm{Cu}= \\
\mathrm{Mo}=\end{array}$ & $\begin{array}{l}\mathrm{W}= \\
\mathrm{Co}=\end{array}$ \\
\hline 處理 & \multicolumn{3}{|c|}{$500^{\circ} \mathrm{C} \times 5 \mathrm{hr}$ 加熱静楊中放彾せる 60} \\
\hline 硬度 & B.H.N. 25 & 倍率 & $\times 150$ \\
\hline 腐蝕 & \multicolumn{3}{|c|}{ 5\% ビクリン酸アルコール } \\
\hline 組繊 & \multicolumn{3}{|c|}{ オーステナイト十トルースタイト } \\
\hline
\end{tabular}

諸溫度に燒戻した場合の抗張力・降伏點・仲の 變化を示したすので, $500^{\circ} \sim 900^{\circ} \mathrm{C}$ 間の燒戻 のものの降伏點は昇るか，抗張力・伸の著し く下る事がわかる．其の理由は炭化物の析出 するため而も此の炭化物の析出狀態は燒入銅 の燒戻の場合とは異なり結節狀ドルースタイ トか出來るためである。

其の組織は第 18 㘣に示した榚である。

今, 更に燒戻溫度と是等機悈的諸性質の變 化を示すと第 15 表の㥞である．即ち $350^{\circ} \mathrm{C}$ 以上に再加熱すると抗張力も伸も著しく下か： 第 15 表

\begin{tabular}{|c|c|c|}
\hline 燒 庆 ${ }^{\circ}{ }^{\circ} \mathrm{C}$ & $\begin{array}{c}\text { 抗 張 } \\
\mathrm{kg} / \mathrm{mm}^{2}\end{array}$ & 伸 \\
\hline 260 & 117 & 57.6 \\
\hline 260 & 120 & 53,0 \\
\hline 315 & 124 & 63.5 \\
\hline 315 & 115 & 55.0 \\
\hline 344 & 90 & 15.6 \\
\hline 344 & 97 & 21.7 \\
\hline 372 & 97 & 3.6 \\
\hline 372 & 82 & 1.5 \\
\hline
\end{tabular}

る。此の性質を利用して高マンガン鋼の穴開 け・切削等が行はれる、郎ち最も粘性の强い 燒入狀態で切別不可能な場合も，之を $350^{\circ} \mathrm{C}$ 位に再加熱して硬度は上るが，粘さの下から た狀態として加工する事が出來る．加工後に 更に高溫から再び急泠せね妨ならない事は云 ふ迄もない。

最近ではタングステンカーバイト系の刃 先又はコパルト含量の高い高速度鋼を適當に 調質したもの等で水冷鲒のるの在切剈する事 加出來る。

然し何れにするも是等の加工は困難で工費 
のからる作業であるから，出來るげけ仕上代＼cjkstart方法としては正常な方法である。

の少い狀態に䥂造してグラインダー仕上げに＼cjkstart第 16 表は高マンガン鋼䥂物製品の化學組 よつて製品を作る方法が本鋼種の製品の加工 成と機械的性質との貝例にある。

第 16 表

\begin{tabular}{|c|c|c|c|c|c|c|c|c|c|c|c|c|c|}
\hline C & $\mathrm{Si}$ & $\mathbf{M n}$ & $\mathbf{P}$ & S & $\mathrm{Cu}$ & $\mathrm{Cr}$ & 降伏點 & 抗張力 & 伸 & 絞 & 硬度 & 衝拏值 & 熱處 理 \\
\hline 1.00 & 0.43 & 13.38 & 0.074 & 0.059 & & & 56.7 & 101.0 & 60.5 & & 207 & & $1000^{\circ} \mathrm{C}$ 水鈍 \\
\hline 0.75 & 0.61 & 12.88 & 0.019 & 0.036 & & & 43.2 & 98.2 & 61.0 & & 187 & & $n$ \\
\hline 1.42 & 0.16 & 13.20 & 0.053 & & 0.019 & 0.72 & 56.0 & 100.6 & 38.0 & & 196 & & $"$ \\
\hline 1.01 & 0.52 & 13.32 & 0.051 & & 0.17 & & 50.8 & 102.5 & 55.6 & & 196 & & $"$ \\
\hline 1.10 & 0.17 & 12.79 & 0.058 & 0.014 & & & 29.1 & 56.3 & 40.0 & & 187 & & $"$ \\
\hline
\end{tabular}

